\title{
Speciation and removal of selenium (IV, VI) from water and wastewaters based on dried activated sludge before determination by flame atomic absorption spectrometry
}

Mahdiyeh Ghazizadeha,*, Abdollah Abbasloo and Farzaneh Bivar ${ }^{\mathrm{b}}$

${ }^{a}$ Department of Chemistry, Kerman Branch, Islamic Azad University, Kerman, Iran, P. O. Box 167-7635131

${ }^{b}$ Department of Chemical engineering, Sirjan Branch, Islamic Azad University, Kerman, Iran, P.O. Box 187-78185

A R T I C L E I N F O :

Received 4 Dec 2020

Revised form 9 Feb 2021

Accepted 30 Feb 2021

Available online 30 Mar 2021

Keywords:

Selenium,

Water and wastewater,

Speciation,

Activated sludge,

Biosorption,

Isotherms.

\begin{abstract}
A B S T R A C T
In recent decades, large amount of pollutants enters to the environment due to development of technology. Therefore, it is necessary to use ecofriendly sorbent to eliminate pollutants. In this research, $0.5 \mathrm{~g}$ of a dried activated sludge (DAS) was used for speciation selenium and removal of selenite [Se(IV)] from water and wastewater samples. The effect of operating parameters such as solution $\mathrm{pH}$, the amount of bio-sorbent, contact time, temperature and initial concentration of selenium were studied by flame atomic absorption spectrometry (F-AAS). Kinetic data was adjusted to the Langmuir and Freundlich kinetic equations. The resulted showed that the Langmuir equation with a correlation coefficient of 0.9825 has the best match to tetravalent selenium biosorption on DAS. The FT-IR results showed that the biosorption mechanism of Se(IV) on DAS is due to functional groups on the DAS surface (Se(IV).... DAS). For reduction of soluble selenate $\left[\mathrm{Se}(V I), \mathrm{SeO}_{4}{ }^{2-}\right]$ to selenite $\left[\mathrm{Se}(I V), \mathrm{SeO}_{3}{ }^{2-}\right]$, the concentrated $\mathrm{HCl}$ was used at $70^{\circ} \mathrm{C}$ (30 min). So, the $\mathrm{Se}(\mathrm{VI})$ reduced to $\mathrm{Se}(\mathrm{IV})$ and total selenium (TSe) was determined and the Se (VI) was simply calculated by difference of TSe from Se(IV) content. The method was validated based on spiking samples in water and wastewater samples by F-AAS and using HG-AAS.
\end{abstract}

\section{Introduction}

Recently, the selenium studies are considered strongly because of the direct correlation between biological functions and the amount of selenium inter the body $[1,2]$. Selenium is an essential bioelement and has an important role in the proper biological functioning of many organisms [3, 4], although it becomes toxic when the concentration is more than $1.7 \mu \mathrm{g} \mathrm{L}^{-1}$ [5]. Modern industrial processes such as the oil refining, the electrolytic copper refining, the

\footnotetext{
*Corresponding Author: Mahdiyeh Ghazizadeh

Email: ghazizadeh1385@gmail.com

https://doi.org/10.24200/amecj.v4.i01.119
}

glass manufacturing, the agriculture and mining activities increase the selenium concentration in the environment matrixes [6-8]. Selenium is also used in thermal power stations, the solar panels, insecticides, semiconductors and rectifires [9]. Two species of this element exist in aqueous systems contain $\mathrm{Se}(\mathrm{IV})$ and $\mathrm{Se}(\mathrm{VI})$ in the form of selenite $\left(\mathrm{SeO}_{3}{ }^{2-}\right)$ and selenite $\left(\mathrm{SeO}_{4}{ }^{2-}\right)$, respectively. $\mathrm{Se}(\mathrm{IV})$ is more toxic than $\mathrm{Se}(\mathrm{VI})[2,10]$. World Health Organization (WHO) proposed the permissible limit of selenium concentration in drinking water should be below $10 \mu \mathrm{g} \mathrm{L}^{-1}$ [11-14]. Therefore, removal of selenium from wastewaters by an 
economic and effective methods is necessary. The most appropriate methods for removing selenium from contaminated water include catalytic reduction, chemical precipitation, electrochemical process, evaporation, floatation, ion exchange, membrane processes, biosorption and adsorption $[2,15]$. Most of these techniques are expensive and improper for removal of selenium from aqueous samples. However, biosorption can be an effective and ecofriendly method for this purpose. Low cost and availability are two major factors for using biomass to remove the environmental pollutant $[15,16]$. Biosorption of selenium by several sorbents such as seaweed, crustacean shell, peanut shell, rice barn, maize, wheat and dry yeast biomass is reported [17-20]. Recently the usage of DAS for removing selenium is extended [21, 22]. In addition, the different instrumental analysis was used for determination of selenium and other metals in different matrixes [23-27]. In this study, the removal of selenium by DAS from aqueous solutions were studied by F-AAS and validated by HG-AAS. The effect of $\mathrm{pH}$, concentration, temperature and contact time was investigated. Kinetic models and thermodynamic parameters were determined.

\section{Experimental}

\subsection{Chemicals}

Sodium selenite $\left(\mathrm{Na}_{2} \mathrm{SeO}_{3}\right)$ with a purity of $98 \%$, was purchased from Merck (India) and used as a source of $\mathrm{Se}(\mathrm{IV})$ ions in the aqueous samples for analytical purpose, sodium hydroxide $(\mathrm{NaOH})$ with a purity of $98 \%$ was purchased from Merck (Darmstadt, Germany, http://www.merck.com), hydrochloric acid $(\mathrm{HCl})$ with a purity of $37 \%$ was purchased from Merck (Darmstadt, Germany, http://www.merck.com), dried activated sludge was obtained from Kerman Zamzam refinery, Iran. The different concentration of Selenium was prepared by dilution of deionized water (DW) and ultrapure water was purchased from Millipore Company. The acetate and phosphate buffer was used to adjust the $\mathrm{pH}$ between 2.6-6.4 and 6.4-8.0, respectively.

\subsection{Apparatus}

Flame atomic absorption spectrometer (F-AAS, Varian spectra 220 model, Australia) with wavelength $196.0 \mathrm{~nm}$; slit $1.0 \mathrm{~nm}$; current $10 \mathrm{~mA}$ was used (10-200 $\left.\mathrm{mg} \mathrm{L}^{-1}\right)$. The hydride generation atomic absorption spectrometer (HG-AAS, 1-100

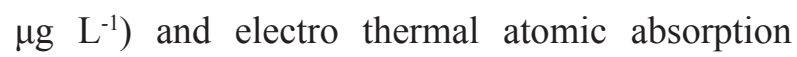
spectrometer (ET-AAS, 15- $400 \mu \mathrm{g} \mathrm{L}^{-1}$ ) were applied as ultra-trace analysis for Se (IV). The analytical $\mathrm{pH}$ meter (Benchtop meter inoLab $\mathrm{pH}$ 7110 model, WTW company, Germany), analytical balance (ALC model, Acculab company, America), magnetic hitter stirrer (IKA RH basic 2 model, IKA company, Germany), and centrifuge (EBA 20 model, Hettich company, Germany) were used for this study.

\subsection{Preparation of dried activated sludge as a biosorbent}

The activated sludge obtained from Zamzam company was suspended in a beaker containing 500 $\mathrm{ml}$ of deionized water on a magnetic stirrer for a day at $25^{\circ} \mathrm{C}$. Let the suspension to precipitate. Then the upper liquid was decanted and the remaining suspension was centrifuged. The resulted sludge was washed with deionized water several times to be neutralized. The collected sample was dried in oven at $80^{\circ} \mathrm{C}$ for $36 \mathrm{~h}$. The dried biomass was powdered and sieved with mesh No. 25.

\subsection{Preparation of sample and selenium solutions}

All glass or PCV tubes were cleaned with a $2 \mathrm{M}$ of $\mathrm{HNO}_{3}$ solution for at least one day and then washed for ten times with ultrapure water. As low concentrations of $\mathrm{Se}(\mathrm{IV})$ and $\mathrm{Se}(\mathrm{VI})$ in water samples, the ion contamination effected on results of analysis, so, we used ultra-trace reagents for sampling processes. Sodium selenite was used to prepare a selenium stock solution with concentration of $1000 \mathrm{ppm}\left(\mathrm{mg} \mathrm{L}^{-1}\right)$. The desired solutions obtained of diluting stock solution. The diluted solutions with concentrations in the range 2-9.5 ppm were used for calibration. 


\subsection{SPE procedure and Batch experiments}

Biosorption of Se(IV) by DAS was achieved in optimized experimental conditions such as $\mathrm{pH}$, contact time, amount of biosorbent and temperature. The experiments were carried out in $100 \mathrm{ml}$ Erlenmeyer flasks. Experiments were achieved with pH 2 to 9, contact time 2 to 35 minute, amount of biosorbent 0.5 to $3 \mathrm{~g}$, temperature 10 to $40^{\circ} \mathrm{C}$ and selenium concentration 10 to $140 \mathrm{mg} \mathrm{L}^{-1}$. To adjust required $\mathrm{pH}$ of aqueous solution, $\mathrm{HCl} 0.2 \mathrm{M}$ and $\mathrm{NaOH} 0.1 \mathrm{M}$ were added. Finally, the kinetic models and isotherms were studied. The absorption capacity of DAS for Se(IV) was obtained $124.2 \mathrm{mg} \mathrm{g}^{-1}$ by 140 $\mathrm{mg} \mathrm{L}^{-1}$ selenium concentration and $1 \mathrm{~g}$ of DAS.

By solid phase extraction procedure (SPE), $0.5 \mathrm{~g}$ of biosorbent of DAS added to $100 \mathrm{~mL}$ of water and wastewater solution and shaked for $15 \mathrm{~min}$ at $\mathrm{pH}=5$. After adsorption, based on chemical bonding between DAS with $\mathrm{Se}(\mathrm{IV})\left[-\mathrm{NH}^{+}:-\mathrm{NH}_{2}^{+}----\mathrm{SeO}_{3}{ }^{2-}\right]$ the solid phase separated/collected in bottom of tube and removed upper liquid phase of water/ wastewater. Finally, the Se(IV) determined with F-AAS after desorption Se(IV) from DAS by adding of $\mathrm{HNO}_{3}(0.5 \mathrm{M}, 5 \mathrm{~mL})$. The concentration $\mathrm{Se}(\mathrm{IV})$ validated by HG-AAS after dilution with DW. For reduction of $\mathrm{Se}(\mathrm{VI})$ to $\mathrm{Se}(\mathrm{IV})$ the concentrated $\mathrm{HCl}$ $(50 \%)$ was used at $70^{\circ} \mathrm{C}$ for $30 \mathrm{~min}$. After reduction, the total selenium (TSe) was determined and the $\mathrm{Se}$ (VI) was simply calculated by difference of TSe from Se(IV) content. The linear range(LR), LOD, perconcentration factor (PF) and recovery were obtained 0.5-10.2 $\mathrm{mg} \mathrm{L}^{-1}, 0.12 \mathrm{mg} \mathrm{L}^{-1}$ and 19.8, and $96.5 \%$, respectively

\section{Results and discussion}

\subsection{FT-IR analysis}

Fourier Transform Infrared (FT-IR) spectrum of DAS was recorded (Fig. 1) to gain the information about surface functional group. As seen in this spectrum, the stretching vibrations of hydroxyl group $(-\mathrm{OH})$ on DAS surface gives the broad and strong band at $3443 \mathrm{~cm}^{-1}$. The weak peaks at about $2300 \mathrm{~cm}^{-1}$ show the stretching vibrations of $-\mathrm{NH}$, $-\mathrm{NH}^{+},-\mathrm{NH}_{2}^{+}$functional groups of DAS. The band peak at $1646 \mathrm{~cm}^{-1}$ refers to stretching vibrations of $-\mathrm{C}=\mathrm{O}$ group. The stretching vibrations of $-\mathrm{C}-\mathrm{O}$ group appears at $1088 \mathrm{~cm}^{-1}$. The band peak at 876 $\mathrm{cm}^{-1}$ is concerned to carbonate group.

\subsection{Effect of $p H$}

The effect of $\mathrm{pH}$ on the biosorption of Se (IV) by DAS were studied at $\mathrm{pH}$ in the range of 2 to 11 for SPE. First, $100 \mathrm{~mL}$ selenium solution with concentration 2-9.5 ppm (mg L-1) and 0.5 g DAS at temperature of $25^{\circ} \mathrm{C}(15 \mathrm{~min})$ was used. The results were shown in Figure 2. Three species of selenium in these aqueous solutions include selenite $\left(\mathrm{SeO}_{3}{ }^{2-}\right)$, biselenite $\left(\mathrm{HSeO}_{3}^{-}\right)$and selenious

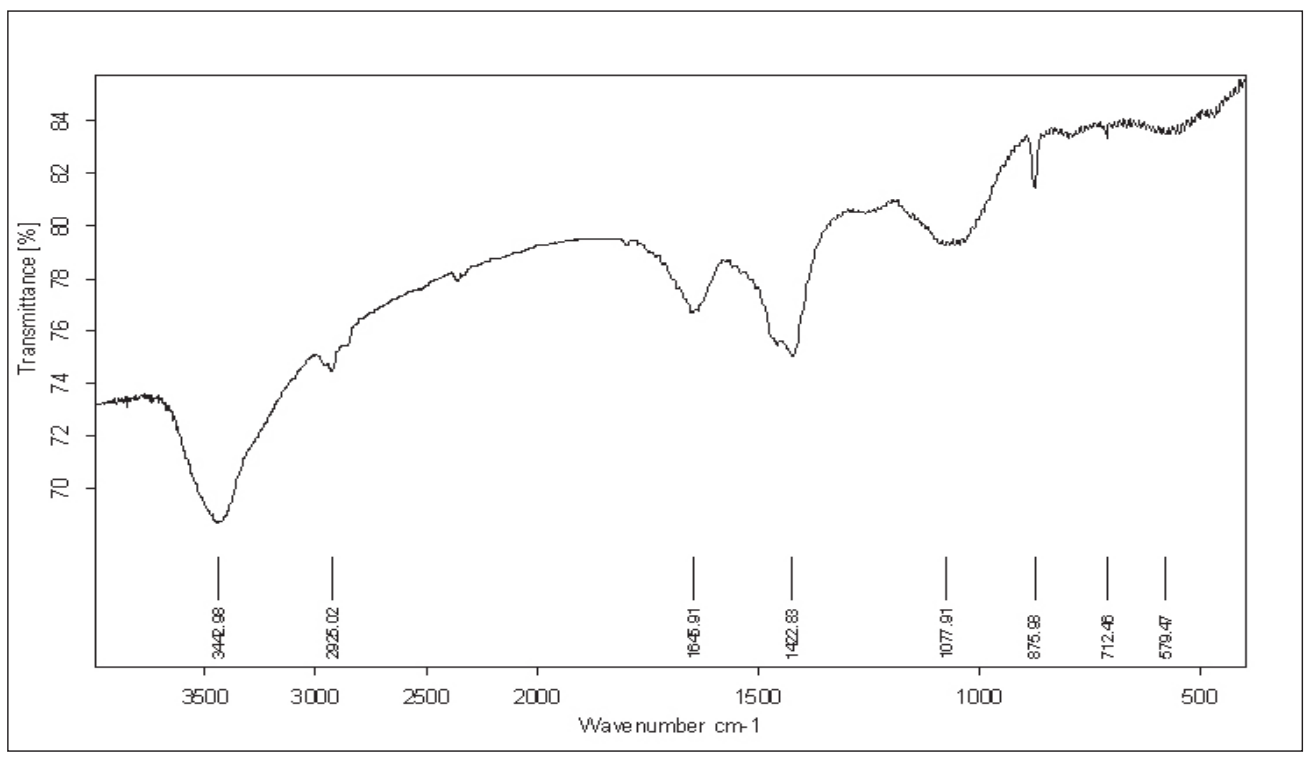

Fig.1. Fourier Transform Infrared (FT-IR) spectrum of DAS 
acid $\left(\mathrm{H}_{2} \mathrm{SeO}_{3}\right)[28,29]$. The selenious acid prevails when $\mathrm{pH}$ decreases below 3.5, biselenite prevails when $\mathrm{pH}$ is in the range of 3.5 to 9 [2]. The lowest selenium biosorption at $\mathrm{pH}$ less than 3.5 is because of inability of neutral selenious acid to interact electrostatically with the DAS. In this work, the highest chemical biosorption of Se(IV) based on DAS was achieved with high recovery more than $95 \%$ for batch system and SPE procedure at $\mathrm{pH}=5$.

\subsection{Effect of contact time}

The effect of contact time, as the next parameter was investigated in the range of 2 to 35 minute at $\mathrm{pH}=5$. As observed in Figure 3, the most proper contact time for selenium biosorption was obtained 15 minutes for SPE. After this contact time, equilibrium occurred. The best time for batch system was obtained $30 \mathrm{~min}(2 \mathrm{~g})$ for selenium concentration 10 to $140 \mathrm{mg} \mathrm{L}^{-1}$.

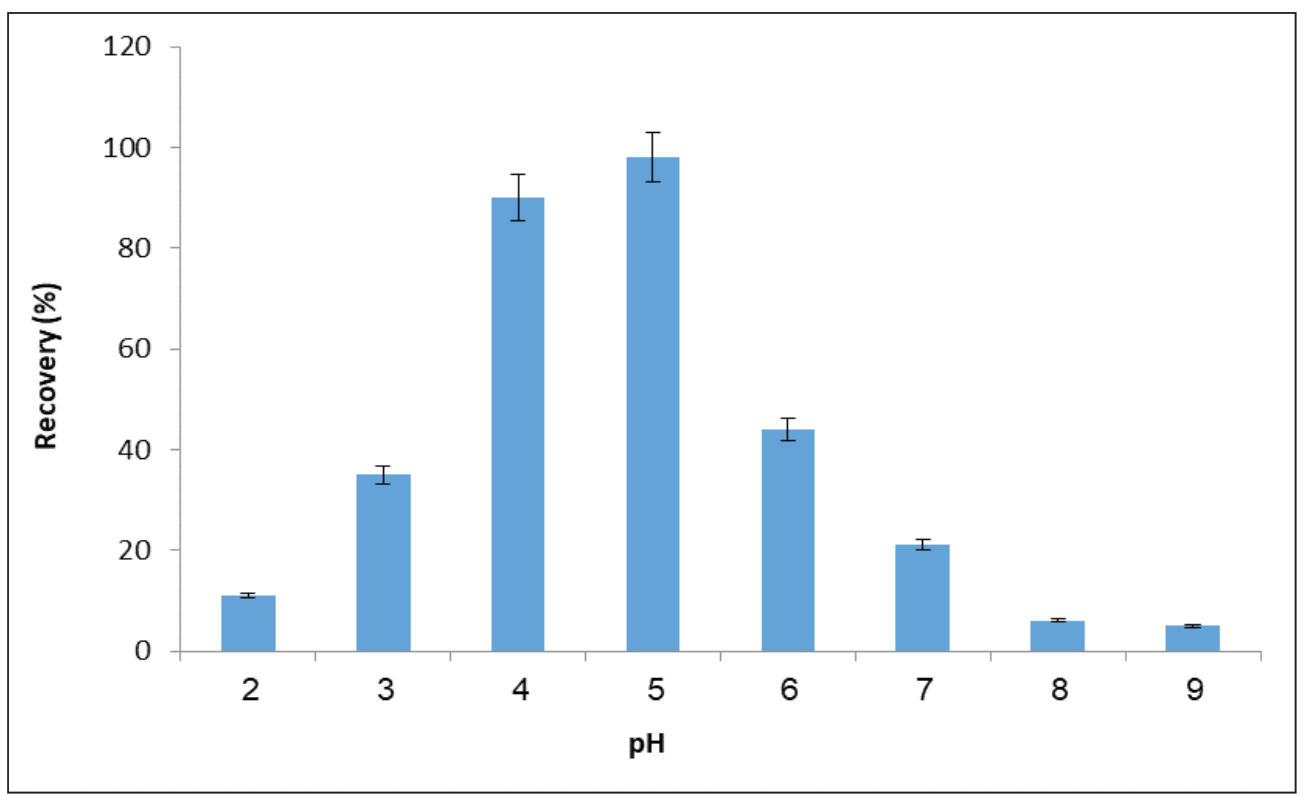

Fig.2. The effect of $\mathrm{pH}$ on $\mathrm{Se}(\mathrm{IV})$ removal from water and wastewater by DAS

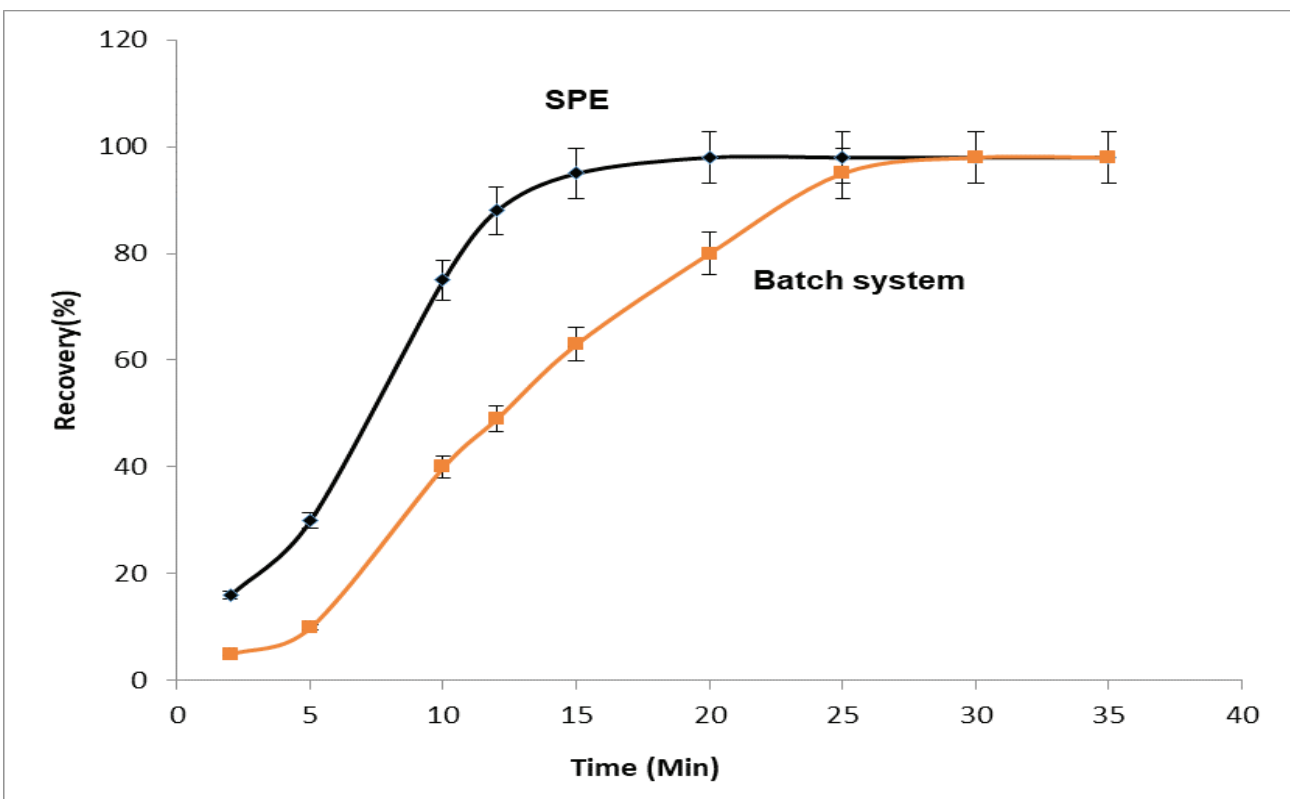

Fig.3. The effect of contact time for removal of Se(IV) from water and wastewater by DAS 


\subsection{Effect of amount of biosorbent}

The effect of amount of biosorbent was investigated under optimized conditions $(\mathrm{pH}=5$ and contact time: 30 min.). As shown in Figure 4, the selenium biosorption increased slowly with the DAS amount up to $2 \mathrm{~g}$ for batch system. The DAS surface becomes saturated with the extra Se(IV) ions in optimized amount of DAS. Therefore, a number of $\mathrm{Se}(\mathrm{IV})$ ions remain in solution and biosorption yield decreased. At higher amount of DAS, biosorption yield is almost unchanged. Because most of Se(IV) ions interact with DAS surface. For SPE, the $0.5 \mathrm{~g}$ of DAS is favorite mass for removal of Se (IV) in water samples with high recovery more than $95 \%$.

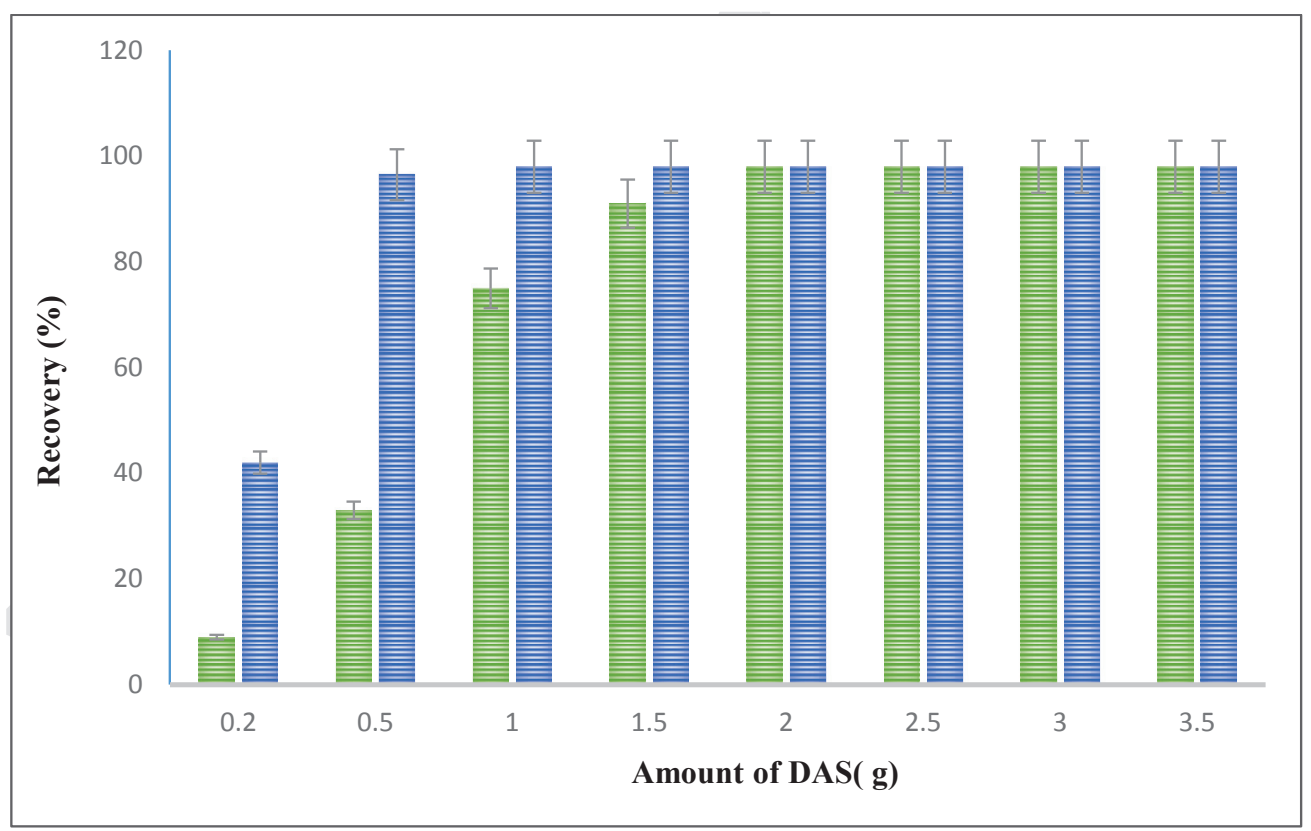

Fig. 4. The effect of biosorbent amount on Se(IV) removal in batch system (green) and SPE procedure(blue) in water and wastewater by DAS

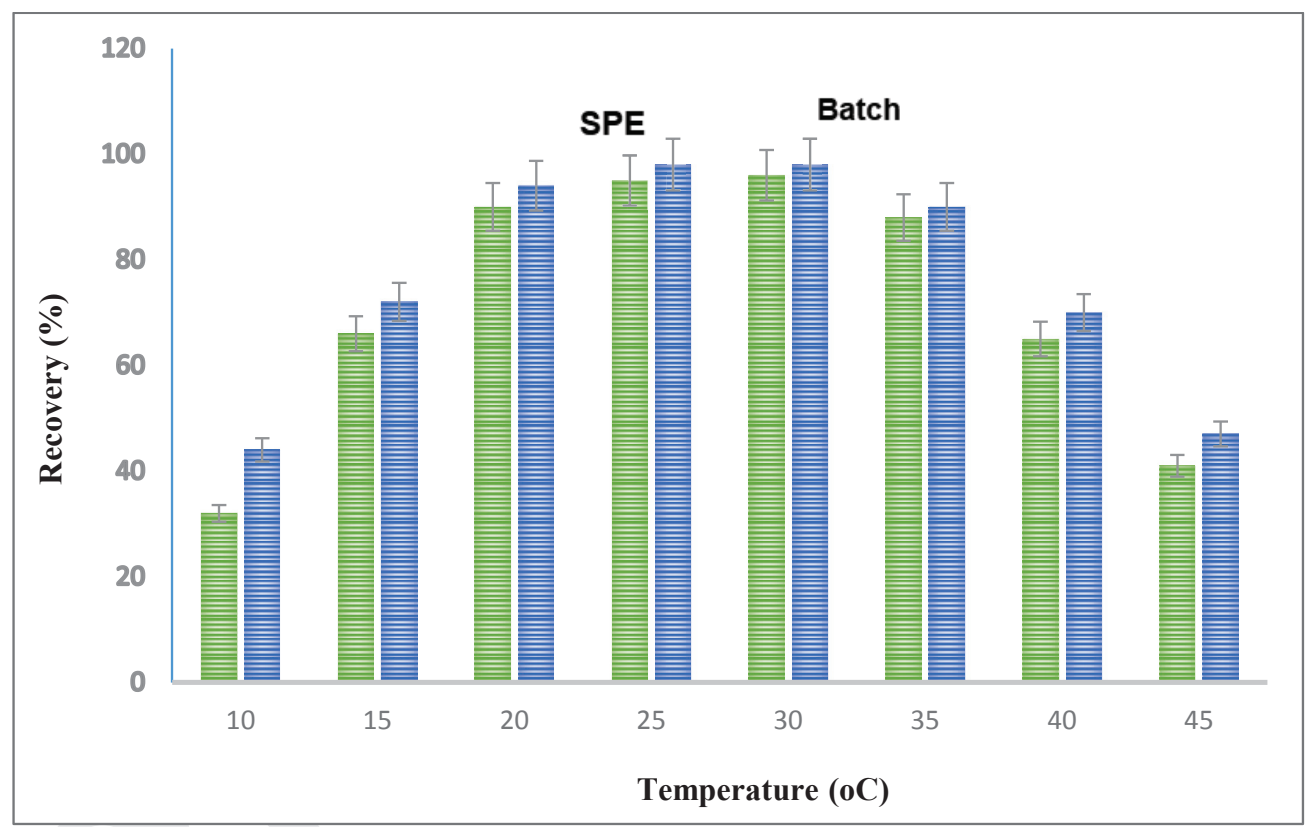

Fig. 5. The effect of temperature on Se(IV) removal in batch system (blue) and SPE procedure(green)from water and wastewater samples by DAS 


\subsection{Effect of temperature}

The effect of temperature on selenium biosorption was investigated between $10-45^{\circ} \mathrm{C}$ in optimized condition. The results showed us, the optimum temperature was achieved $30^{\circ} \mathrm{C}$ in optimized condition $(\mathrm{pH}$, contact time and amount of biosorbent DAS were 5, 30 minute and $2 \mathrm{~g}$, respectively). Due to Figure 5, by increasing temperature, the selenium biosorption decreased. It indicated the biosorption by DAS is an exothermic reaction. The best temperature for SPE procedure for DAS was $25-30^{\circ} \mathrm{C}$.

\subsection{Effect of initial concentration of selenium}

Effect of initial concentration of selenium in the range of 20-250 ppm was investigated for absorption capacity. The results indicated that increasing selenium concentration caused to more absorb of the selenium on DAS and decreased the selenium concentration in the solution. The number of sites on DAS were interacted with Se(IV) ions and can be saturated at high concentrations of selenium ions. According to obtained results, the adsorption capacity of $\mathrm{Se}(\mathrm{IV})$ ions on DAS increased up to $124.2 \mathrm{mg} \mathrm{g}^{-1}$ [AC; mg per gram]. The results have presented in Figure 6.

\subsection{Kenetic isotherms for $\mathrm{Se}(\mathrm{IV})$ and $\mathrm{Se}$ (VI)}

The most popular isotherms are Langmuir $[21,30]$ and Freundlich $[21,31]$ models. The Langmuir model describes monolayer adsorption, however Freundlich model show heterogeneous surface. The linear form of Langmuir model is given by following equation I:

$$
\frac{C_{\mathrm{e}}}{q_{\mathrm{e}}}=\frac{1}{\left(K_{\mathrm{L}} q_{\mathrm{m}}\right)}+\frac{C_{\mathrm{e}}}{q_{\mathrm{m}}}
$$

where $\mathrm{Ce}\left(\mathrm{mg} \mathrm{L}^{-1}\right)$ is the equilibrium concentration of the solution, qe $\left(\mathrm{mg} \mathrm{g}^{-1}\right)$ is the amount of metal adsorbed per specific amount of adsorbent, $\mathrm{qm}\left(\mathrm{mg} \mathrm{g}^{-1}\right)$ is the maximum amount of metal ions required to form monolayer, $\mathrm{K}(\mathrm{L}$ $\left.\mathrm{mg}^{-1}\right)$ is the adsorption equilibrium constant.

The linear form of Freundlich model is given by following equation II:

$$
\log \left(q_{\mathrm{e}}\right)=\log \left(K_{\mathrm{F}}\right)+\left(\frac{1}{n}\right) \log C_{\mathrm{e}}
$$

where $\mathrm{n}$ is the adsorption intensity and $\mathrm{K}_{\mathrm{F}}$ is the adsorption capacity.

The amount of Se(VI) adsorbed on DAS at equilibrium (qe, $\mathrm{mg} \mathrm{g}^{-1}$ ) was calculated by Equation (III):

$$
\mathrm{q}_{\mathrm{e}}=\left(\mathrm{C}_{0}-\mathrm{C}_{\mathrm{e}}\right) \times V / \mathrm{m}
$$

(Eq. III)

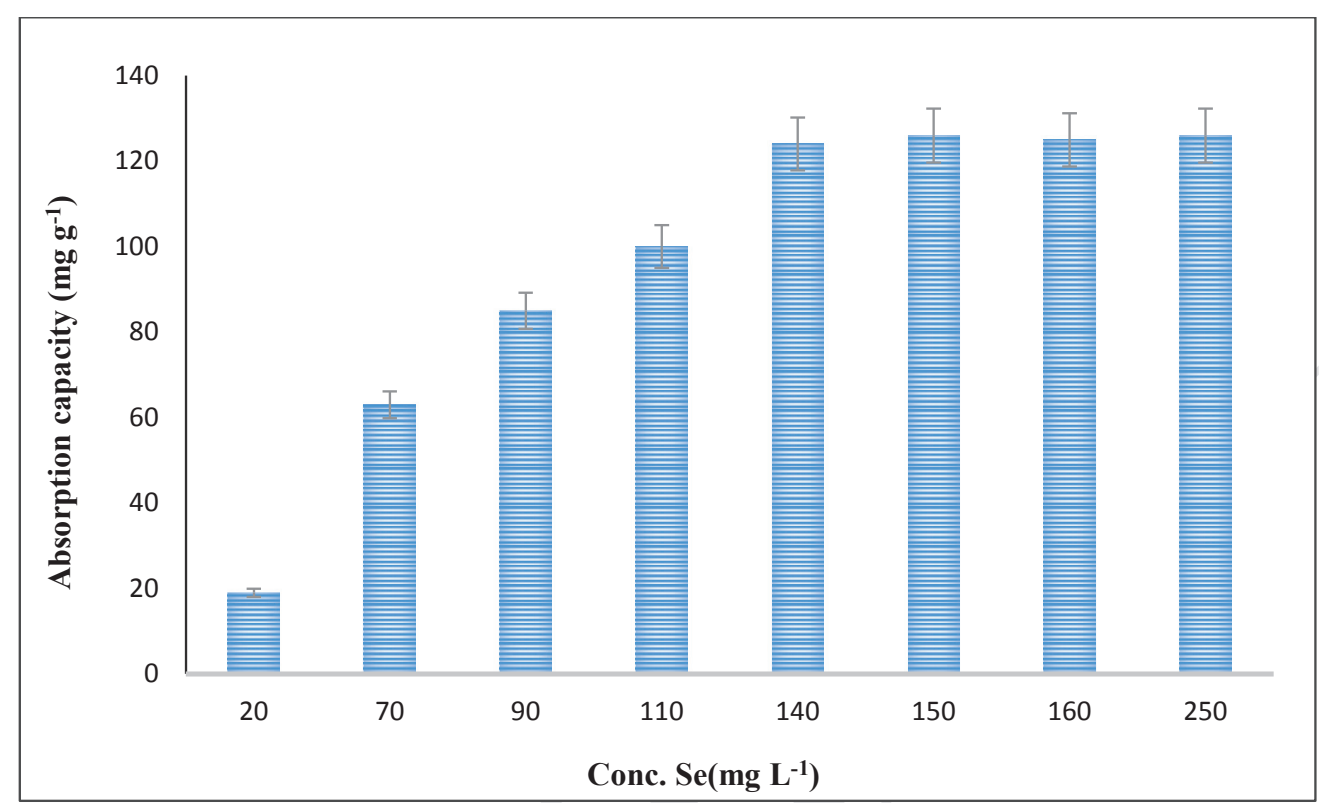

Fig. 6. The effect of initial concentration of Se(IV) ions on absorption capacity of DAS in water and wastewater samples 
where $\mathrm{C}_{0}$ and $\mathrm{C}_{\mathrm{e}}\left(\mathrm{mg} \mathrm{L}^{-1}\right)$ are the initial and equilibrium $\mathrm{Se}(\mathrm{VI})$ concentrations, respectively, $V$ (L) is the volume of the solution and $\mathrm{m}(\mathrm{g})$ is the mass of the adsorbent. $\left(\mathrm{C}_{0}=10-250 \mathrm{mg} \mathrm{L}^{-1}, \mathrm{C}_{0}=250\right.$ $\mathrm{mg} \mathrm{L}^{-1}$ and $\mathrm{C}_{\mathrm{e}}=190 \mathrm{mg} \mathrm{L}^{-1}, V=0.1 \mathrm{~L}, \mathrm{~m}=0.05 \mathrm{~g}$ ). So the $\mathrm{qe}, \mathrm{q}_{\max }$ and $\mathrm{C}_{\mathrm{e}} / \mathrm{q}_{\mathrm{e}}$ was obtained as $120 \mathrm{mg}$ $\mathrm{g}^{-1}, 120 \mathrm{mg} \mathrm{g}^{-1}$ and 2.08, respectively. As different concentrations, the $\mathrm{C}_{\mathrm{e}} / \mathrm{q}_{\mathrm{e}}$ were calculated based on Langmuir model between 0.02-2.08.

Linear Langmuir equation was considered to gain isotherm (Fig. 7). The $\mathrm{Se}(\mathrm{VI})$ in solutions with different initial concentrations $\left(\mathrm{C}_{0}=10-250 \mathrm{mg}\right.$ $\mathrm{L}^{-1}$ ) were used. Langmuir constants, $\mathrm{K}_{\mathrm{L}}$ and $\mathrm{q}_{\mathrm{m}}$ were calculated from the slope and intercept of the plot $\mathrm{Ce} / \mathrm{qe}$ versus Ce.

As Figure 8, the linear Freundlich isotherm of Se(IV) and $\mathrm{Se}(\mathrm{VI})$ is a another kenetic model for DAS. Freundlich isotherm parameters, $\mathrm{K}_{\mathrm{F}}$ and $1 / \mathrm{n}$ were calculated from the slope and intercept of linear plot.

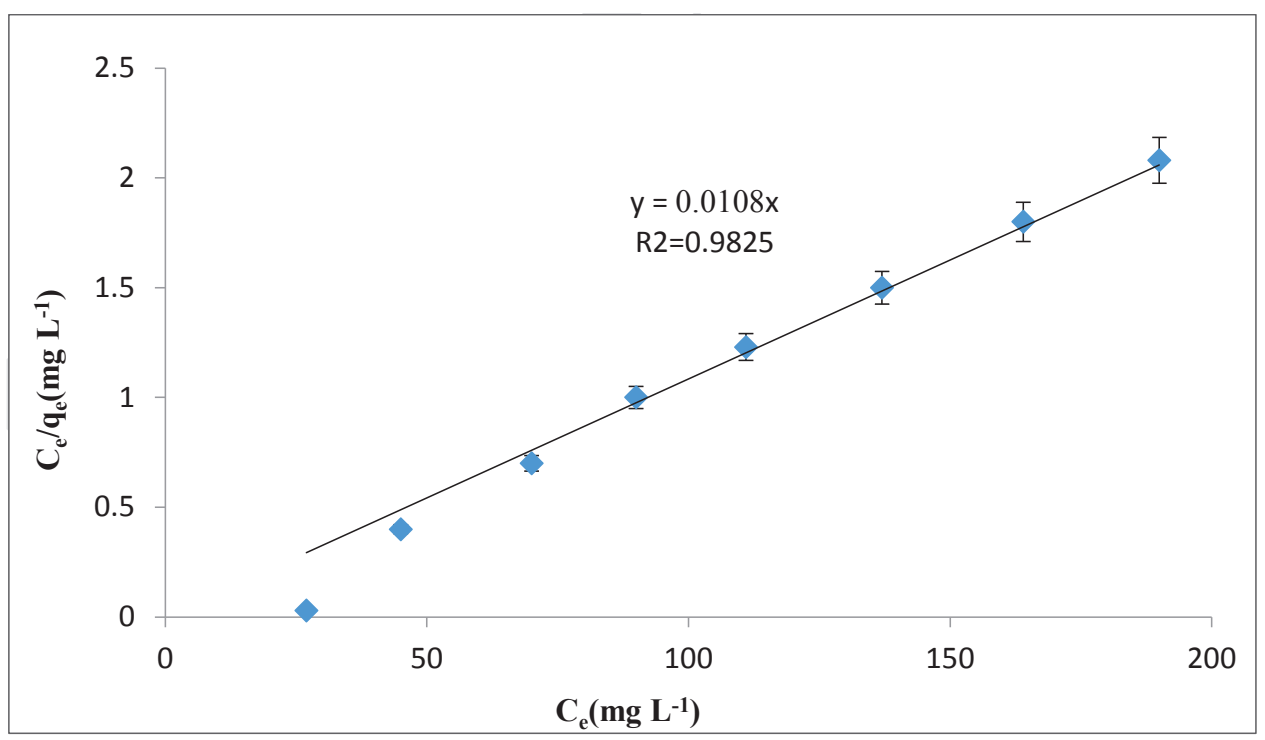

Fig. 7. Linear Langmuir equation for selenium removal by DAS biosorbents from water and wastewater samples

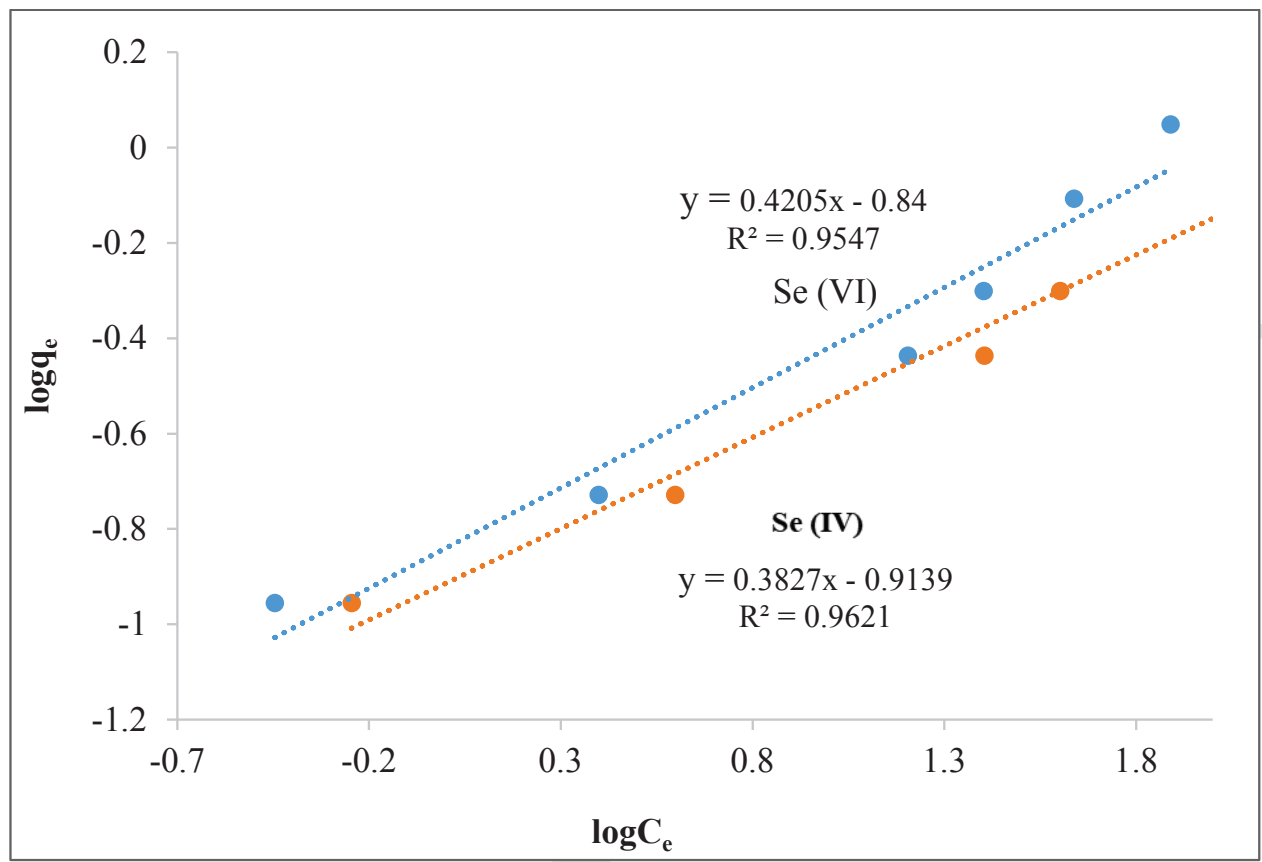

Fig. 8. Linear Freundlich isotherm for selenium removal by DAS biosorbents from water and wastewater samples 


\subsection{Validation of SPE procedure}

The selenium was removed and determined in $100 \mathrm{~mL}$ of water and wastewater samples based on DAS with SPE procedure at $\mathrm{pH}=5$. The mean concentration of $\mathrm{Se}(\mathrm{IV})$ more than $\mathrm{Se}(\mathrm{VI})$ in water samples. The spiked water was used to demonstrate the reliability of the method for determination of $\mathrm{Se}(\mathrm{IV})$ and $\mathrm{Se}(\mathrm{VI})$ in water samples by $\mathrm{SPE}$ procedure. The recovery of spiked samples showed a satisfactorily result for determination of $\mathrm{Se}$ (IV) and $\mathrm{Se}(\mathrm{VI})$ in water samples (Table 1). Moreover, the real water samples were analyzed with HGAAS/ET-AAS and used for validation of results of SPE/F-AAS procedure. The results showed, the favorite efficiency and reliability of proposed method for determination selenium in water and wastewater sample which was compared to ETAAS and HG-AAS (Table 2)

Table 1. Validation of SPE procedure based on DAS for speciation selenium (VI, IV) in water and wastewater samples $\left(\mathrm{mg} \mathrm{L}^{-1} ; \mathrm{n}=8\right)$

\begin{tabular}{|c|c|c|c|c|c|c|c|}
\hline Sample & $\begin{array}{c}\text { Added } \\
\operatorname{Se}(I V)\end{array}$ & $\begin{array}{l}\text { Added } \\
\operatorname{Se}(V I)\end{array}$ & $\begin{array}{l}{ }^{*} \text { Found } \\
\text { Se(IV) }\end{array}$ & $\begin{array}{l}\text { *Found } \\
\operatorname{Se}(V I)\end{array}$ & $\begin{array}{l}\text { Total } \\
\text { TSe }\end{array}$ & $\begin{array}{l}\text { Recovery } \\
\text { Se(IV) (\%) }\end{array}$ & $\begin{array}{l}\text { Recovery } \\
\operatorname{Se}(\text { VI) }(\%)\end{array}$ \\
\hline \multirow[t]{2}{*}{ Wastewater 1} & ----- & ----- & $4.45 \pm 0.19$ & $1.23 \pm 0.05$ & $5.68 \pm 0.24$ & ----- & ----- \\
\hline & 4.0 & 0.5 & $8.29 \pm 0.37$ & $1.75 \pm 0.07$ & $10 . .04 \pm 0.45$ & 96.0 & 104 \\
\hline \multirow[t]{2}{*}{ Wastewater 2} & ----- & ----- & $3.86 \pm 0.18$ & $0.56 \pm 0.03$ & $4.42 \pm 0.22$ & ----- & ----- \\
\hline & 4.0 & 0.5 & $7.81 \pm 0.35$ & $1.03 \pm 0.05$ & $8.84 \pm 0.42$ & 98.8 & 94.7 \\
\hline \multirow[t]{2}{*}{ Wastewater 3} & ----- & ----- & $1.95 \pm 0.14$ & $1.47 \pm 0.08$ & $3.42 \pm 0.15$ & ----- & ----- \\
\hline & 2.0 & 1.5 & $3.98 \pm 0.19$ & $2.95 \pm 0.14$ & $6.93 \pm 0.34$ & 101.5 & 98.6 \\
\hline \multirow[t]{2}{*}{ River } & ----- & ----- & ND & ND & ND & ----- & ----- \\
\hline & 2.0 & 2.0 & $1.97 \pm 0.11$ & $2.07 \pm 4.4$ & $4.04 \pm 0.21$ & 94.9 & 103.5 \\
\hline
\end{tabular}

$* x \pm t s / \sqrt{ } n$ at $95 \%$ confidence $(n=8)$

Well water prepared from Varamin agricultural

Wastewater 1 prepared from drug company

Wastewater 2 prepared from petrochemical factory

Wastewater 3 prepared from paint factory

River water prepared from Karaj

Table 2. Comparing of proposed procedure for selenium determination by F-AAS/DAS with HG-AAS and ET-AAS

\begin{tabular}{cccc}
\hline Sample & F-AAS $/ \mathbf{D A S}\left(\mathrm{mg} \mathrm{L}^{-1}\right)$ & ET-AAS $\left(\boldsymbol{\mu g ~ \mathbf { L } ^ { - 1 } ) ^ { * }}\right.$ & *HG-AAS $\left(\boldsymbol{\mu g} \mathbf{L}^{-1}\right)$ \\
\hline Wastewater* & $0.55 \pm 0.25$ & ND & $5.36 \pm 0.52$ \\
\hline Water & ND & $41.3 \pm 13.81$ & $40.9 \pm 13.81$ \\
\hline
\end{tabular}

$x \pm t$ s $/$ N at $95 \%$ confidence $(n=5)$

*Wastewater 1 prepared from drug company, $1 \mathrm{~mL}$ of sample diluted with DW up to 100 (1:100) 


\section{Conclusions}

In this study, the results showed tetravalent selenium ions $\left(\mathrm{Se}_{\mathrm{IV}}\right)$ biosorption were successfully achieved by DAS from contaminated aqueous solutions. The maximum removal of Se(IV) ions was $96 \%$ at optimized experimental conditions by SPE/F-AAS. The interaction between Se(IV) ions and functional groups of DAS surface was exothermic. The experimental data were fitted to Freundlich isotherm. Also the speciation Se(IV) and $\mathrm{Se}$ (VI) ions determined based on DAS by SPE procedure for $0.5 \mathrm{~g}$ of DAS at $\mathrm{pH}=5$. The method was validated by ET-AAS and HG-AAS. The absorption capacities for Se(IV) and Se (VI) ions with DAS were achieved $124.2 \mathrm{mg} \mathrm{g}^{-1}$ and 121.8 $\mathrm{mg} \mathrm{g}^{-1}$, respectively.

\section{Acknowledgments}

The authors would like to thank from Department of Chemistry, Kerman Branch, Islamic Azad University, Kerman, Iran.

\section{References}

[1] M. Kashiwa, S. Nishimoto, K. Takahashi, M. Ike, M. Fujita, Factors affecting soluble selenium removal by a selenite reduciing bacterium Bacillus sp. SF-1, J. Biosci. Bioeng., 89 (2000) 528-533.

[2] M. Tuzen, A. Sari, Biosorption of selenium from aqueous solution by green alga (Cladophorahutchinsiae) biomass: Equilibrium, thermodynamic and kinetic studies, Chem. Eng. J., 158 (2010) 200-206.

[3] M. Rovira, J. Gimienez, M. Martiinez, X. Marttinez-Lladio, J. Pablo, V. Martii, L. Duro, Sorption of selenium(IV) and selenium(VI) onto natural iron oxides: goethite and hematite, J. Hazard. Mater., 150 (2008) 279284.

[4] F.M. Fordyce, selenium deficiency and toxicity in the environment, Essentials of Medical Geology, Elsevier Academic Press, Amsterdam, Holland, pp.373-416, 2005.

[5] K. Nettem, A.S. Almusallam, Equilibrium, kinetic, and themodynamic studies on the biosorption of selenium (IV) ions onto Ganoderma Lucidum Biomass, Sep. Sci. Tech., 48 (2013) 2293-2301.

[6] H. Robberecht, R.V. Grieken, Selenium in environmental water: determination, speciation and concentration levels, Talanta, 29 (1982) 823-844.

[7] J. Lessa, A. Araujo, G. Silva, L. Guilherme, G. Lopes, Adsorption-desorption reactions of selenium (VI) in tropical cultivated and uncultivated soils under Cerrado biome, Chemosphere, 164 (2016) 271-277.

[8] S. Santos, G. Ungureanu, R. Boaventura, C. Botelho, Selenium contaminated waters: an overview of analytical methods, treatment options and recent advances in sorption methods, Sci. Total Environ., 521-522 (2015) 246-260.

[9] E.I. El-Shafey, Sorption of Cd(II) and Se(IV) from aqueous solution using modified rice husk, J. Hazard. Matter., 147 (2007) 546- 555.

[10] F.Sahin, M. Volkan, A.G. Howard, O.Y. Ataman, Selective preconcentration of selenite from aqueous samples using mercapto-silica, Talanta, 60 (2003) 1003-1009.

[11] G. Kallis, D. Butler, The EU water framework directive: measures and implications, Water Policy, 3 (2001) 125- 142.

[12] O.Y. Bakather, A. Kayvani fard, Ihsanullah, M. Khraisheh, M.S. Nasser, M.A. Atieh, Enhanced adsorption of selenium ions from aqueous solution using iron oxide impregnated carbon nanotubes, Bioinorg. Chem. Appl., 2017 (2017) 1-12.

[13] M. Kieliszek, S. Blazejak, K. Piwowarek, K. Brzezicka, Equilibrium modeling of selenium binding from aqueous solutions by Candida atilis ATCC 9950 yeasts, Biotech., 8 (2018) 388: doi: 10.1007/s13205-018-1415-8.

[14] F.A. Bertolino, A.A.J. Torriero, E. Salinas, R. Olsina, L.D. Martinez. J. Raba, Speciation analysis of selenium in natural water using square-wave voltammetry after preconcentration on activated carbon, Anal. Chim. Acta, 572 (2006) 32-38. 
[15] S. Dev, A. Khamkhash, T. Ghosh, S. Aggarwal, Adsorptive removal of Se(IV) by Citrus peels: Effect of adsorbent entrapment in calcium alginate beads, ACS Omega, 5 (2020) 1721517222.

[16] R.H.S.F. Vieira, B. Volesky, Biosorption: a solution to pollution, Int. Microbiol., 3 (2000) 17-24.

[17] D.A. Roberts, N.A. Paul, S.A. Dworjanyn, Y. Hu, M.I. Bird, R. de Nys, Gracilaria waste biomass (sampah rumput laut) as a bioresource for selenium biosorption, J. Appl. Phycol., 27 (2015) 611-620.

[18] S.H. Hasan, D. Ranjan, Agro-industerial waste: a low-cost option for the biosorptive remediation of selenium anions, Ind. Eng. Chem. Res., 49 (2010) 8927-8934.

[19] S. Beeram, A. Morris, C.J. Hardway, J.C. Richert, J. Sneddon, Studies of whole crawfish shells for the removal of chromium, lead and selenium ions in solution, Instrum. Sci. Technol., 40 (2012) 618-639.

[20] H. Khakpour, H. Younesi, M. Mohammadhosseini, Two-stage biosorption of selenium from aqueous solution using dried biomass of the baker's yeast Saccharomyces cerevisiae, J. Environ. Chem. Eng., 2 (2014) 532-542.

[21] H. Zare, H. Heydarzadeh, M. Rahimnejad, A. Tardast, M. Seyfi, S.M. Peyghambarzade, Dried activated sludge as an appropriate biosorbent for removal of copper (II) ions, Arab. J. Chem., 8 (2015) 858-864.

[22] L. Bennamoun, P. Arlabosse, A. Leonard. Review on fundamental aspect of application of drying process to wastewater sludge, Renew. Sust. Energ. Rev., 28 (2013) 29-43.

[23] H. Shirkhanloo, F. Golbabaei, H. Hassani, F. Eftekhar, M.J. Kian, Occupational exposure to mercury: air exposure assessment and biological monitoring based on dispersive ionic liquid-liquid microextraction, Iran. J. Public Health, 43 (2014) 793.

[24] S. Golkhah, H. Zavvar Mousavi, H. Shirkhanloo, A. Khaligh, Removal of Pb (II) and $\mathrm{Cu}$ (II) Ions from Aqueous Solutions by Cadmium Sulfide Nanoparticles, Int. J. Nanosci. Nanotechnol., 13 (2017) 105-117.

[25] H. Shirkhanloo, A. Khaligh, H.Z. Mousavi, A. Rashidi, Graphene oxide-packed microcolumn solid-phase extraction combined with flame atomic absorption spectrometry for determination of lead (II) and nickel (II) in water samples, Int. J. Environ. Anal. Chem., 95 (2015) 16-32.

[26] M. Arjomandi, H. Shirkhanloo, A review: Analytical methods for heavy metals determination in environment and human samples, Anal. Methods Environ. Chem. J., 2 (2019) 97-126.

[27] H. Shirkhanloo, S. A. H. Mirzahosseini, N. Shirkhanloo, The evaluation and determination of heavy metals pollution in edible vegetables, water and soil in the south of Tehran province by GIS, Arch. Environ. Protec., 41 (2015) 64-74.

[28] M. Duc, G. Lefevre, M. Fedoroff, Sorption of selenite ions on hematite, J. Colloid Interface Sci., 298 (2006) 556-563.

[29] T. Nishimura, H. Hashimoto, M. Nakayama, Removal of selenium(VI) from aqueous solution with poly-amine type weakly basic ion exchange resin, Sep. Sci. Technol., 42 (2007) 3155-3167.

[30] I. Langmuir, The adsorption of gases on plane surfaces of glass, mica and platinum, J. Am. Chem. Soc., 40 (1918) 1361-1403.

[31] H. Freundlich, Adsorption in solution. J. Phys. Chem., 57 (1906) 384-410. 